\title{
Global-scale pattern of peatland Sphagnum growth driven by photosynthetically active radiation and growing season length
}

\author{
J. Loisel ${ }^{1}$, A. V. Gallego-Sala ${ }^{2,3,4}$, and Z. Yu ${ }^{1}$ \\ ${ }^{1}$ Department of Earth and Environmental Sciences, Lehigh University, 1 West Packer Avenue, Bethlehem, \\ PA 18015-3001, USA \\ ${ }^{2}$ Department of Earth and Ecosystem Science, Lunds Universitet, Sölvegatan 12, 22362 Lund, Sweden \\ ${ }^{3}$ Geography, College of Life and Environmental Sciences, University of Exeter, Amory Building, Rennes Drive, \\ Exeter EX4 4RJ, UK \\ ${ }^{4}$ School of Geographical Sciences, University of Bristol, University Road, Bristol BS8 1SS, UK
}

Correspondence to: J. Loisel (jul208@lehigh.edu)

Received: 18 January 2012 - Published in Biogeosciences Discuss.: 27 February 2012

Revised: 18 June 2012 - Accepted: 27 June 2012 - Published: 30 July 2012

\begin{abstract}
High-latitude peatlands contain about one third of the world's soil organic carbon, most of which is derived from partly decomposed Sphagnum (peat moss) plants. We conducted a meta-analysis based on a global data set of Sphagnum growth measurements collected from published literature to investigate the effects of bioclimatic variables on Sphagnum growth. Analysis of variance and general linear models were used to relate Sphagnum magellanicum and $S$. fuscum growth rates to photosynthetically active radiation integrated over the growing season (PAR0) and a moisture index. We found that PAR0 was the main predictor of Sphagnum growth for the global data set, and effective moisture was only correlated with moss growth at continental sites. The strong correlation between Sphagnum growth and PAR0 suggests the existence of a global pattern of growth, with slow rates under cool climate and short growing seasons, highlighting the important role of growing season length in explaining peatland biomass production. Large-scale patterns of cloudiness during the growing season might also limit moss growth. Although considerable uncertainty remains over the carbon balance of peatlands under a changing climate, our results suggest that increasing PAR0 as a result of global warming and lengthening growing seasons, without major change in cloudiness, could promote Sphagnum growth. Assuming that production and decomposition have the same sensitivity to temperature, this enhanced growth could lead to greater peat-carbon sequestration, inducing a negative feedback to climate change.
\end{abstract}

\section{Introduction}

Peatlands are wetland ecosystems that are primarily distributed across the boreal and subarctic regions of the world. They cover about $3 \%$ of the global land area, and represent at least half of the world's wetlands. In these ecosystems, net primary production (NPP) exceeds decomposition, resulting in the formation and accumulation of carbon-rich peat deposits that can be up to tens of meters thick (Rydin and Jeglum, 2006). Since the last deglaciation, peatlands have accumulated over 600 gigatons of organic carbon $(\mathrm{GtC})$ globally (Yu et al., 2010), which constitutes up to about a third of the global soil organic C. Many paleoecological and modeling studies have shown that inter-annual, centennial, and millennial changes in peat- $\mathrm{C}$ accumulation rates are mainly controlled by the regional climate (e.g., Mauquoy et al., 2002; Malmer and Wallén, 2004; Frolking et al., 2010), and that warming might promote peat-C sequestration in temperaturesensitive regions by increasing NPP more than decomposition (Frolking et al., 2003; Beilman et al., 2009; Jones and $\mathrm{Yu}, 2010$; Charman et al., 2012; Loisel and Yu, 2012). These results point to a potential increase in the peat- $\mathrm{C}$ sink capacity under the ongoing and projected climate warming, which would result in a negative feedback to climate change. However, this finding remains a matter of considerable debate, because warming is also expected to promote peat decomposition via direct enhanced microbial decomposition or indirect drying of the peatland surface (Ise et al., 2008; Dorrepaal

Published by Copernicus Publications on behalf of the European Geosciences Union. 
et al., 2009). Sphagnum (peat moss) forms vast, nearly continuous carpets that dominate the groundcover of most highlatitude peatlands. Although these bryophytes usually do not contribute the largest proportion of peatland NPP (Blodau, 2002), they possess recalcitrant tissues that resist microbial breakdown (van Breemen, 1995) and release phenolic compounds that inhibit microbial decomposition (Freeman et al., 2001), making them more decay-resistant than most other peatland plants. As a result, partly decomposed Sphagnum remnants account for about $50 \%$ of the peatland organic matter (Rydin and Jeglum, 2006). Over time, the imbalance between production and decomposition leads to the formation of Sphagnum-rich peat deposits. For this reason, Sphagnum is often referred to as the main "peat builder", and Sphagnum might store more organic $\mathrm{C}$ than any other plant genus worldwide (Clymo and Hayward, 1982; Wieder, 2006).

Each Sphagnum species possesses a well-defined ecological niche that is primarily based on peatland surface-moisture conditions, with dry-adapted species forming hummocks, wet-adapted species growing in hollows, and intermediate species colonizing lawns. In general, Sphagnum NPP increases along this dry-to-wet moisture gradient, with highest productivity under wet conditions (van Breemen, 1995). However, the rate of decomposition is also highest in wet microhabitats, as wet-adapted species preferentially allocate their resources into labile metabolic carbohydrates rather than in recalcitrant structural carbohydrates (Turetsky et al., 2008). Mineral nutrient richness and abundance also influence Sphagnum distribution in peatlands with, in general, a higher diversity in groundwater-fed systems (fens) and less variety in acidic, precipitation-fed peatlands (bogs). Overall, species that inhabit wet fens (e.g., Sphagnum cuspidatum) are generally characterized by the highest growth values, whereas dry bog hummocks (e.g., Sphagnum fuscum) have the lowest productivity (Gunnarsson, 2005).

Sphagnum growth form is sensitive to local environmental conditions, as mosses are unable to actively regulate carbon uptake and water loss because they lack stomata. For example, mosses growing in wet hollows reside in a less dense carpet than mosses growing on drier hummocks (Titus and Wagner, 1984). These wet-adapted species also possess less-developed capillary water transport systems and have a smaller water-holding capacity than dry-adapted species. As a result, mosses growing in wet hollows are typically responsible for the largest variability in growth rate at the local scale: As soon as the water table gets closer to the peatland surface, they grow quickly because of efficient resource allocation strategies, but they also desiccate quickly following water table drawdown (Titus and Wagner, 1984). Dryadapted species are more resilient to local moisture changes, mostly because of their ability to retain moisture (Luken, 1985). For example, Sphagnum fuscum and S. magellanicum are generally considered dry-adapted species, as they typically grow on hummocks and lawns, where they form densely packed communities to avoid desiccation (Rydin and
Jeglum, 2006). This growth form is a consequence of the preferential resource allocation to structural carbohydrates (Turetsky et al., 2008), and results in a strongly vertical growth component.

Sphagnum productivity has been the object of a series of observational and modeling studies over the past $30 \mathrm{yr}$ (see Wieder, 2006, for a review). Many studies have found a positive relationship between Sphagnum NPP and annual or summer temperature (Moore, 1989; Dorrepaal et al., 2003; Gunnarsson, 2005; Breeuwer et al., 2008), or higher Sphagnum productivity at lower latitudes (Wieder and Lang, 1983). However, several studies have found no temperature effect or even a reduction in NPP with increasing temperature, possibly because of moisture stress and dehydration (Weltzin et al., 2001; Gerdol et al., 2007). It was also suggested that higher evapotranspiration as a result of higher temperature might lead to reduced Sphagnum NPP (Skre and Oechel, 1981).

In his review on Sphagnum productivity, Gunnarsson (2005) found that moss growth was strongly correlated to taxonomic sections (Acutifolia vs. Cuspidata), site-specific microhabitat characteristics (hummocks vs. hollows), and broad climatic gradients. He shows that mean annual temperature and precipitation together explained about $40 \%$ of the variance in moss growth, with temperature having the most important effect. The study by Gunnarsson (2005) constituted the first and only compilation effort that aimed at understanding both local- and large-scale controls on peat moss growth. In terms of identifying the effects of climate on Sphagnum growth, however, the work by Gunnarsson (2005) has one major drawback: The database included 31 Sphagnum species, from which many were (i) very poorly represented ( 22 out of the 31 species have less than 10 growth measurements), (ii) limited in their geographic range (some species are solely found in maritime, subarctic, or nutrientrich peatlands), and (iii) characterized by very different productivity values due to phylogeny and microhabitat preferences (e.g., oligotrophic hummock species vs. eutrophic hollow species). This collection of a large number of species might have hindered the detection of fundamental effects of climatic gradients on Sphagnum productivity. In contrast, the present study focuses on a synthesis of the climatic factors that influence peatland Sphagnum growth using the two most well-studied and abundant species: S. fuscum and S. magellanicum. This approach should improve our ability to establish large-scale geographic and bioclimatic effects on moss growth by reducing the amount of noise induced by speciesspecific features.

\section{Research question and rationale}

In general, warming is expected to increase plant productivity in cold regions (Nemani et al., 2003; Hudson and Henry, 2009). In the boreal and subarctic ecoregions, 


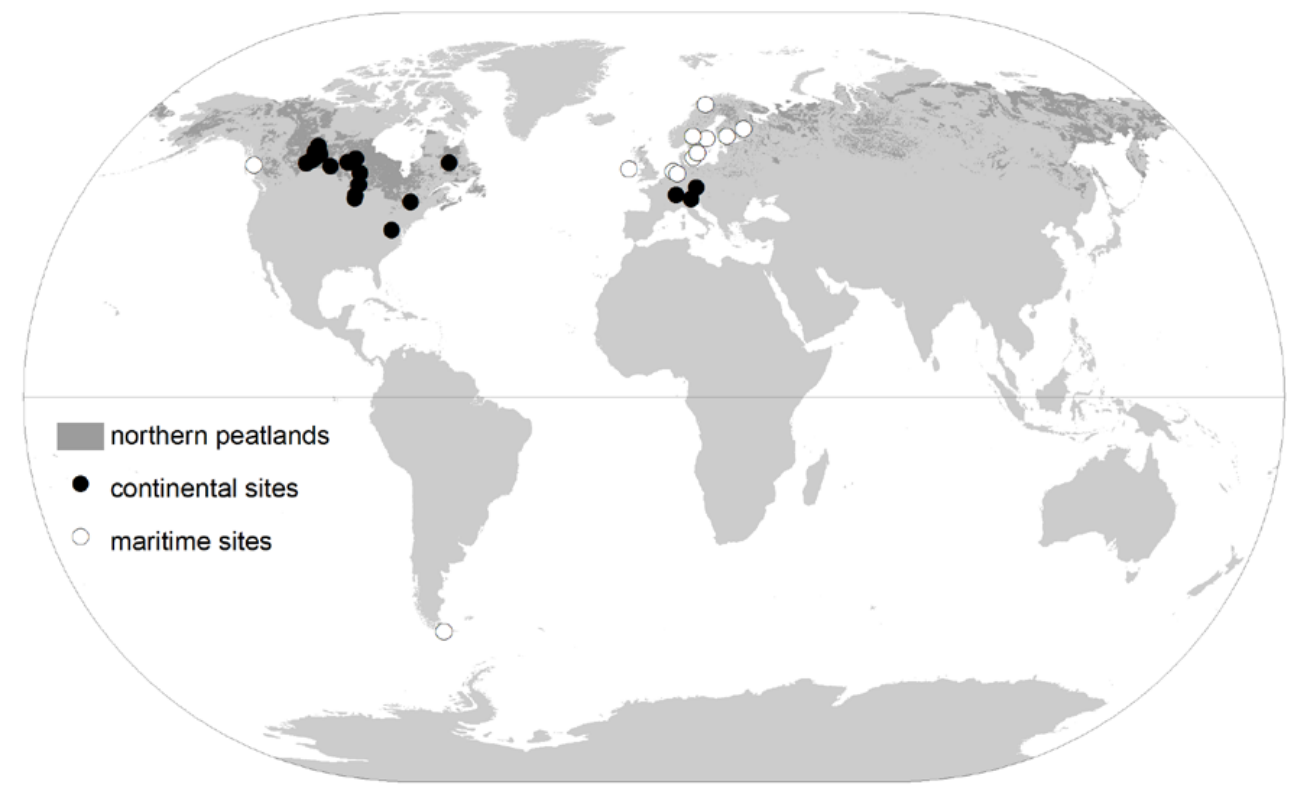

Fig. 1. Global distribution of study sites $(n=52)$ with Sphagnum growth measurements $(n=142)$. Black circles indicate continental sites and open circles show maritime sites. The dark shaded area represents the northern peatland extent from Yu et al. (2010).

warming-induced increases in the growing season length (early spring warming) and earlier snowmelt (water availability) are also believed to change the phenology of plants and promote $\mathrm{C}$ sequestration in many ecosystems (e.g., Aurela et al., 2004; Menzel et al., 2006; Schwartz et al., 2006; Stelzer and Post, 2009). These effects should be especially beneficial for Sphagnum species, because spring photosynthesis starts as soon as (i) the snow cover disappears (or even before complete disappearance), and (ii) daily temperatures reach $0{ }^{\circ} \mathrm{C}$, since these non-vascular plants do not root into the colder soil (Moore et al., 2006).

The objective of the present study is to investigate whether the estimated annual growth of two Sphagnum species (S. magellanicum and S. fuscum) can be related to broad environmental controls, namely light, temperature, growing season length, and available moisture. Here we examine largescale patterns of Sphagnum growth using published moss growth values as well as new thermal and moisture indexes. Given that a large amount of peatlands are characterized by extended Sphagnum carpets, this study intends to assess the impacts of past, present, and future change in growing season length, PAR, and available moisture on peat biomass production, one of the two most important $\mathrm{C}$ flux terms of peatland ecosystems (the other one being peat decomposition).
Table 1. Distribution of Sphagnum growth measurements in terms of species, peatland type, microform, and continentality.

\begin{tabular}{llr}
\hline & Subset of data & $\begin{array}{r}\text { Number of } \\
\text { measurements }\end{array}$ \\
\hline \multirow{2}{*}{ Species } & Sphagnum fuscum & 100 \\
& Sphagnum magellanicum & 42 \\
& Bog & 111 \\
Peatland type & Poor fen & 20 \\
& Rich fen & 11 \\
& & \\
Microform & Hummock & 114 \\
& Lawn & 26 \\
& Hollow & 2 \\
Continentality & Continental & 96 \\
& Maritime & 46 \\
\hline
\end{tabular}

\section{Methods}

\subsection{Sphagnum growth}

We compiled a data set of 142 measurements of Sphagnum growth at 52 sites located in North America, Europe, and southern South America. Site latitudes range from $39^{\circ}$ to $68^{\circ}$ (Fig. 1 and Table 1). A detailed description of study sites and references can be found in Supplement S1. We examined each publication and only recorded data from studies that reported in situ, species-specific values of Sphagnum stem height growth ( $\left.\mathrm{HG} ; \mathrm{cm} \mathrm{yr}^{-1}\right)$. All these measurements 
were performed following the cranked wire method (Clymo, 1970), a simple but consistent approach that is widely used in peatland ecology. The accuracy of the cranked wire method is mostly limited by the starting and ending dates of the measurements: If the investigator misses out a portion of the early spring and/or late summer growth, the recorded growth increment will not be representative of the entire growing season and will result in an underestimation of length growth. We assume that all moss growth values used in this study represent all or most of the growing season growth, but we acknowledge that these values most likely represent minimum growth estimates.

Although these HG terms do not take growth form into account, they were preferred over published data of Sphagnum biomass and density, because the latter two types of data were derived using a wide array of techniques that could not be directly compared. For example, Bauer et al. (2007) used shoot density and shoot mass to determine moss bulk density, Berendse et al. (2001) used the dry weight of the upper $3 \mathrm{~cm}$ (including the capitula) of samples that were $7 \mathrm{~cm}$ or $8 \mathrm{~cm}$ in diameter, and Gerdol (1995) averaged the dry weight of 10 capitula. As directly comparing these biomass values would have introduced unquantifiable unknowns in our data set (Clymo, 1970), all the measurements were presented as HG values. This approach is justified since Sphagnum growth is predominantly apical, meaning that moss shoots elongate upwards from their apical meristem (Clymo, 1970). From a morphological standpoint, vertical shoot growth is inversely related to branch density so that slower stem growth typically leads to greater branch density. For example, Sphagnum height growth will be reduced under dry conditions, but the stem volumetric density will increase, allowing the moss to acquire and retain more moisture (Luken, 1985). This acclimation is partly attributable to the production and "delivery" mechanisms of branches, which are formed in the capitulum (plant apex) and transferred to the apical meristem as the stem elongates (Rydin and Jeglum, 2006). For these reasons, we assumed that environmental conditions exert a primary control on stem height growth, which then influences branch density.

To minimize species-specific differences in height growth, only growth data for Sphagnum fuscum $(n=100)$ and S. magellanicum $(n=42)$ were compiled. These dry-adapted species were selected due to their ubiquity (Gunnarsson, 2005). We did not use data from fertilized and other experimental treatments, but Sphagnum measurements from control plots in experimental manipulation studies were included in the database. For each observation, the peatland type (bog, poor fen, or rich fen), the microform on which the Sphagnum was growing (hummock, lawn, or hollow), and site continentality (maritime or continental) were compiled (Table 1). Continental and maritime sites were classified using the temperature difference between June and January mean monthly temperatures. If this temperature difference was greater than $25^{\circ} \mathrm{C}$, they were classified as continental sites (96 sites); oth- erwise, they were classified as maritime (46 sites). Only one growth measurement per site, peatland type, microhabitat, year and species was used. If there were many measurements for one of these categories, the mean productivity value was compiled. Species were well distributed among the continentality classes, with each group composed of $60 \%$ Sphagnum fuscum and $40 \%$ S. magellanicum. Peatland types were also relatively well distributed among the continentality classes with, for example, $8.3 \%$ of continental peatlands being rich fens vs. $6.5 \%$ in the maritime group.

\subsection{Bioclimatic variables}

Effects of climate on Sphagnum height growth were examined using two compound bioclimatic variables. First, a measure of photosynthetically active radiation integrated over the growing season, i.e. over days with mean daily temperature above $0{ }^{\circ} \mathrm{C}$ (PAR0, in mol photons $\mathrm{m}^{-2}$ season $^{-1}$ ), was computed for each site based on a gridded long-term mean climatology (temperature, precipitation, and sunshine hours) with a spatial resolution of $0.5^{\circ}$ for the period 1931-1960 (CLIMATE 2.2; data available at http://www.bridge.bris.ac. uk/projects/PAIN). PAR0 was calculated from latitude, modern orbital parameters and sunshine hours for days with mean daily temperature above $0{ }^{\circ} \mathrm{C}$ (Prentice et al., 1993). The instantaneous PAR flux density is first calculated from the incoming shortwave radiation. An integration of this value between sunrise and sunset yields the average daily PAR. This is averaged over the season taking into account latitude and cloudiness. As PAR0 controls plant $\mathrm{CO}_{2}$ uptake and exerts a direct control on NPP (Chapin et al., 2002), we argue that this variable can be used as a measure of Sphagnum carbon fixation potential. Second, the ratio between annual precipitation $(P)$ and the annually integrated equilibrium evapotranspiration $\left(E_{q}\right)$ was used as an index of moisture balance $\left(P / E_{q}\right)$. Both $P$ and $E_{q}$ were derived from the CLIMATE 2.2 data set. $E_{q}$ is a measure of annual potential evapotranspiration, which is a function of daily net radiation and temperature (Prentice et al., 1993; Harrison et al., 2010). This moisture index provides a measure of annual plant water availability, and it was preferred to other moisture indexes based on empirical evidence that $P / E_{q}$ is a superior predictor of the occurrence of peatlands and peatland types (Gallego-Sala et al., 2010). These bioclimatic variables were analyzed to avoid the multicollinearity that often emerges from studies in which predictor variables are closely related to one another (Zar, 2010). Indeed, preliminary analysis showed strong correlations (multicollinearity $>60 \%$ ) between latitude, growing season temperature (GST) and growing degree days above $0^{\circ} \mathrm{C}$ (GDD0) for our study sites (data not shown). We avoided such strong intercorrelations in our analysis. 

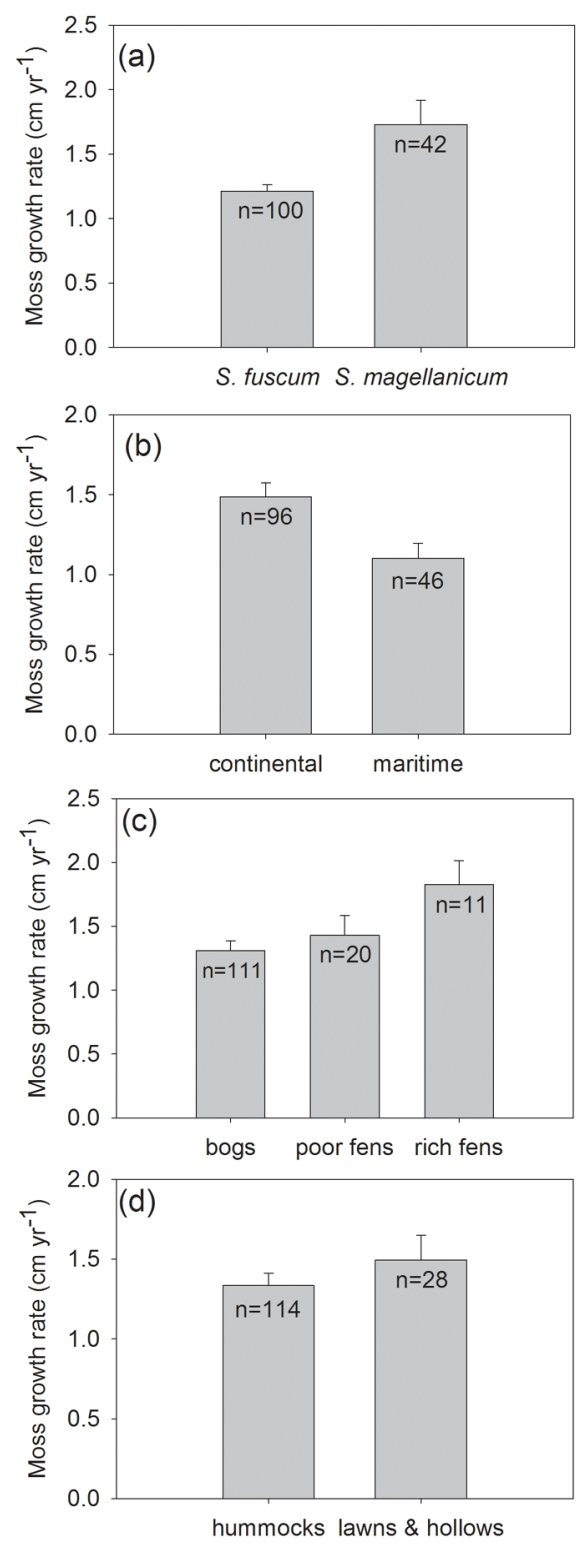

Fig. 2. Sphagnum growth values (mean and standard error) for (a) each species, (b) continentality class, (c) peatland type, and (d) microform.

\subsection{Statistical analysis}

Sphagnum height growth values $\left(\mathrm{cm} \mathrm{yr}^{-1}\right)$ were logtransformed to meet the assumption of homoscedasticity before statistical analysis. Growth differences between Sphagnum species, peatland types, microforms and continentality classes were tested using one-way analysis of variance (ANOVA). To examine the effect of PAR0 and $P / E_{q}$ on Sphagnum growth, we first determined their respective correlation coefficient (Pearson correlation). Simple linear regressions were also performed to obtain the coefficient of determination between each independent variable and Sphagnum
Table 2. Results of one-way analysis of variance (ANOVA) models of Sphagnum growth predicted by species, peatland type, microform, and continentality. df: degree of freedom (the comma separates the number of $\mathrm{df}$ for the numerator and denominator); $p$ : probability.

\begin{tabular}{lrrr}
\hline & df & $F$ & $p$ \\
\hline Species & 1,140 & 5.9 & 0.016 \\
Peatland type & 2,139 & 3.8 & 0.025 \\
Microform & 2,139 & 1.8 & 0.181 \\
Continentality & 1,140 & 13.7 & $<0.0001$ \\
\hline
\end{tabular}

growth. These results were then used to build a multiple regression model where the variable with the highest coefficient of correlation was incorporated first, followed by the second variable as well as by their combined effect. Values were centered prior to the multiple regression analyses. Simple and multiple regression analyses of Sphagnum growth values were performed on (i) all data altogether, and (ii) each continentality class separately. All analyses were performed using PASW Statistics version 18.0 (SPSS Inc., Chicago, IL, USA).

\section{Results}

\subsection{Effect of species, peatland type, microform, and continentality on Sphagnum productivity}

Sphagnum growth rates ranged from 0.1 to $6.0 \mathrm{~cm} \mathrm{yr}^{-1}$, with a mean value of $1.4 \pm 0.8(1 \mathrm{SD}) \mathrm{cm} \mathrm{yr}^{-1}$. The ANOVA revealed a significant effect of species on productivity $(F(1140)=5.931, p=0.016$, Table 2$)$, with Sphagnum magellanicum growing significantly more rapidly than $S$. fuscum (Fig. 2). Similarly, continentality had a strong effect on moss growth $(F(1140)=13.704, p<0.0001$, Table 2), with continental sites characterized by faster growing samples than maritime sites (Fig. 2). Peatland type also had a significant effect on Sphagnum growth $(F(2139)=3.798$, $p=0.025$, Table 2 ), with rich fens being significantly more productive than bogs (Tukey's LSD: $p=0.01$, Fig. 2). Finally, the ANOVA performed on microform did not reveal significant moss growth differences between hummocks and lawns-hollows combined ( $p=0.181$, Table 2; Fig. 2). For all four ANOVAs, the assumption of equality of variance was met (Levene's test: $p>0.05$ ).

\subsection{Relationships between Sphagnum productivity and bioclimatic parameters}

The Pearson correlation coefficient between PAR0 and Sphagnum growth revealed a positive correlation between these variables $(r=0.48, p<0.0001)$. However, $P / E_{q}$ and Sphagnum growth were not correlated $(r=0.01, p=0.456)$. Similarly, simple linear regressions using all data indicated 
Table 3. Results of univariate and multivariate regression models of Sphagnum growth using all values, continental sites, and maritime sites. df: degree of freedom (the comma separates the number of df for the numerator and denominator); $p$ : probability; PAR0 and $P / E_{q}$ are defined in the text.

\begin{tabular}{|c|c|c|c|c|}
\hline data sets & predictor & df & adjusted $R^{2}$ & $p$ \\
\hline \multicolumn{5}{|c|}{ Univariate regression analyses } \\
\hline \multirow{2}{*}{ all sites } & PAR0 & 1,140 & 0.23 & $<0.0001$ \\
\hline & $P / E_{q}$ & 1,140 & 0.00 & 0.912 \\
\hline \multirow{2}{*}{ continental } & PAR0 & 1,94 & 0.31 & $<0.0001$ \\
\hline & $P / E_{q}$ & 1,94 & 0.06 & 0.009 \\
\hline \multirow{2}{*}{ maritime } & PAR0 & 1,44 & 0.02 & 0.172 \\
\hline & $P / E_{q}$ & 1,44 & 0.00 & 0.690 \\
\hline \multicolumn{5}{|c|}{ Multivariate regression analysis } \\
\hline \multirow{3}{*}{ continental } & PAR0 & 2,93 & 0.31 & $<0.0001$ \\
\hline & $P / E_{q}$ & 2,93 & 0.01 & 0.832 \\
\hline & $\mathrm{PAR} 0 \times P / E_{q}$ & 3,92 & 0.04 & 0.444 \\
\hline
\end{tabular}

that PAR0 explained most of the variance in Sphagnum growth $\left(R^{2}=0.23, p<0.0001\right.$, Table 3 , Fig. 3$)$, but that $P / E_{q}$ did not have a significant effect $\left(R^{2}=0.00, p=\right.$ 0.912 , Table 3 ). These patterns were somewhat different when continental and maritime sites were examined separately. While PAR0 explained more of the growth variance among continental sites than when all sites were considered $\left(R^{2}=0.31, p<0.0001\right.$, Table 3, Fig. 3), it was not significant among maritime sites $\left(R^{2}=0.02, p=0.172\right.$, Table 3, Fig. 3). Interestingly, $P / E_{q}$ came out as a significant (though poor) predictor of moss growth in continental settings $\left(R^{2}=0.06, p=0.009\right.$, Table 3$)$, but was not significant across the maritime sites $\left(R^{2}=0.00, p=0.690\right.$, Table 3). A multiple regression analysis performed on PAR0 and $P / E_{q}$ for continental sites indicated that the interaction effect was not significant ( $p=0.444$, Table 3 ), and that these two variables did not explain significantly more variability in Sphagnum growth $\left(R^{2}=0.31\right.$, Table 3$)$ than PAR0 alone $\left(R^{2}=0.31\right)$.

\section{Discussion}

\subsection{Species, peatland type, and microform effects}

At the peatland scale, a large range of Sphagnum growth values is generally found (e.g., Moore, 1989; Campbell et al., 2000). This variability has often been attributed to speciesspecific biochemical mechanisms (Turetsky et al., 2008) and to microhabitat characteristics such as depth to water table (Rydin and Jeglum, 2006) or nutrient input (Bubier et al., 2007). In line with these previous studies, our results indicate that Sphagnum growth was different among

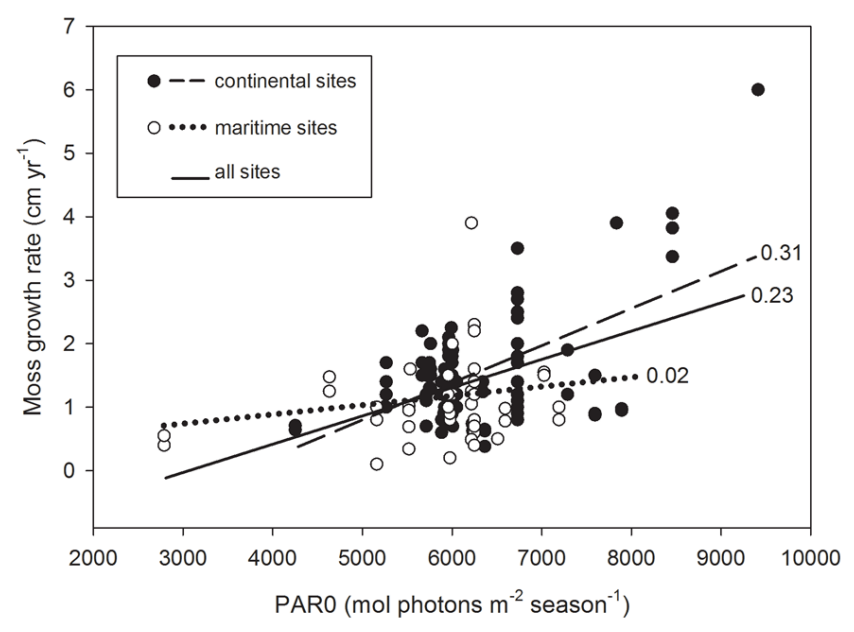

Fig. 3. Photosynthetically active radiation integrated over the growing season (PAR0) in relation to Sphagnum growth. $R^{2}$ values are presented next to the regression lines.

species (S. fuscum vs. S. magellanicum) and peatland types (bogs vs. poor fens vs. rich fens). However, growth was not correlated to microform (hummock vs. lawn-hollow), contrary to the idea that wetter microhabitats such as lawns and hollows favor Sphagnum growth. Since microform classification is arbitrary, it is possible that microforms with similar hydrological and nutrient conditions were classified as low hummocks at a study site but as lawns in another peatland, limiting our ability to distinguish a microform effect on Sphagnum growth. Direct measurements of water table depths would be more useful in analyzing microform influence on moss productivity. A smaller size sample for the lawn-hollow group $(n=28)$ than for the hummock group $(n=114)$ might also have limited the potential for a microform effect to be detected (statistical Type II error). Alternatively, it is possible that a microform effect on growth can only be apparent at the peatland scale (i.e., relative differences within a single ecosystem), but cannot be detected at the global scale.

\subsection{Climatic controls}

Photosynthetically active radiation integrated over the growing season (PAR0) should exert a positive control on peat moss growth in high-latitude regions, because plant growth increases with the amount of radiation received over the growing season. Supporting this hypothesis, PAR0 was the most important variable explaining Sphagnum growth in our analysis, with higher PAR0 values associated with greater growth rates. These results suggest that peat moss growth is primarily driven by PAR and the growing season length, and imply that broad-scale controls on Sphagnum growth are significant despite the effect of local or site-specific factors such as nutrient influx or depth to water table. 
Adequate effective moisture is necessary for peatland development and peat moss growth. In our data synthesis, however, no relationship between moss growth and the moisture index $\left(P / E_{q}\right)$ was found when all sites were considered. These results suggest that, over broad spatial scales, moisture availability does not play a significant role on Sphagnum growth. An adequate moisture supply at the local scale is necessary for peat moss growth, but our results suggest it might only play a secondary role when compared to growing season length, temperature, and PAR.

Sphagnum growth from continental sites was mostly sensitive to PAR0 $(p<0.0001)$ and showed an influence of $P / E_{q}$ $(p=0.009)$. These results suggest that peat moss growth becomes limited with decreasing PAR0 and decreasing moisture availability. In contrast, growth values from maritime sites were neither associated with PAR0 nor $P / E_{q}$. These differences between the continentality classes were not due to a species effect, since each group was composed of $60 \%$ Sphagnum fuscum and $40 \%$ S. magellanicum. Similarly, peatland types were also relatively well distributed among the continentality classes with, for example, $8.3 \%$ of continental peatlands being rich fens vs. $6.5 \%$ in the maritime group.

The climate space of PAR0 and $P / E_{q}$ for the northern peatland domain (Yu et al., 2010) is presented to provide context for our results and future work on peatland-climate relationships (Fig. 4). Northern peatlands typically occur where

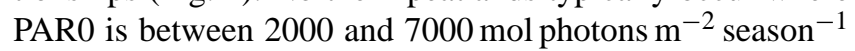
(mean $=4205$ ), and $P / E_{q}$ is between 0.3 and 3 (mean $=1.3$ ). Maritime sites from our study were characterized by significantly lower PAR0 and higher $P / E_{q}$ values than their continental counterparts (Fig. 4). The study sites cover the PAR0 and $P / E_{q}$ climate space relatively well, except for a near-complete absence of data points at PAR0 values lower

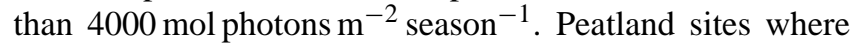
flux tower measurements provide contemporary net ecosystem carbon balance budgets are similarly found in the highest PAR0 and lowest $P / E_{q}$ portion of the climate space (Fig. 4). These results imply that much research is needed in colder, higher-latitude regions (with low PAR0), as well as in areas with higher effective moisture (high $P / E_{q}$ ).

Bioclimatic differences between continental and maritime sites could explain the patterns in Sphagnum growth. For example, continental sites were characterized by significantly higher PAR0 values than the maritime sites, with mean and standard error values of $6181 \pm 83$ and $5959 \pm 134$ mol photons $^{-2}$ season $^{-1}$, respectively ( $p<0.0001$, Fig. $4 \mathrm{~b})$. In addition, growing season temperature (GST) and July temperature were significantly different between maritime and continental sites (data not shown), with maritime regions characterized by cooler GST and July $T$ than their continental counterparts. Cloudiness may be an important limiting factor for moss growth in maritime settings (Blodau, 2002; Mauquoy et al., 2002). In addition, an extended snow cover during spring time in
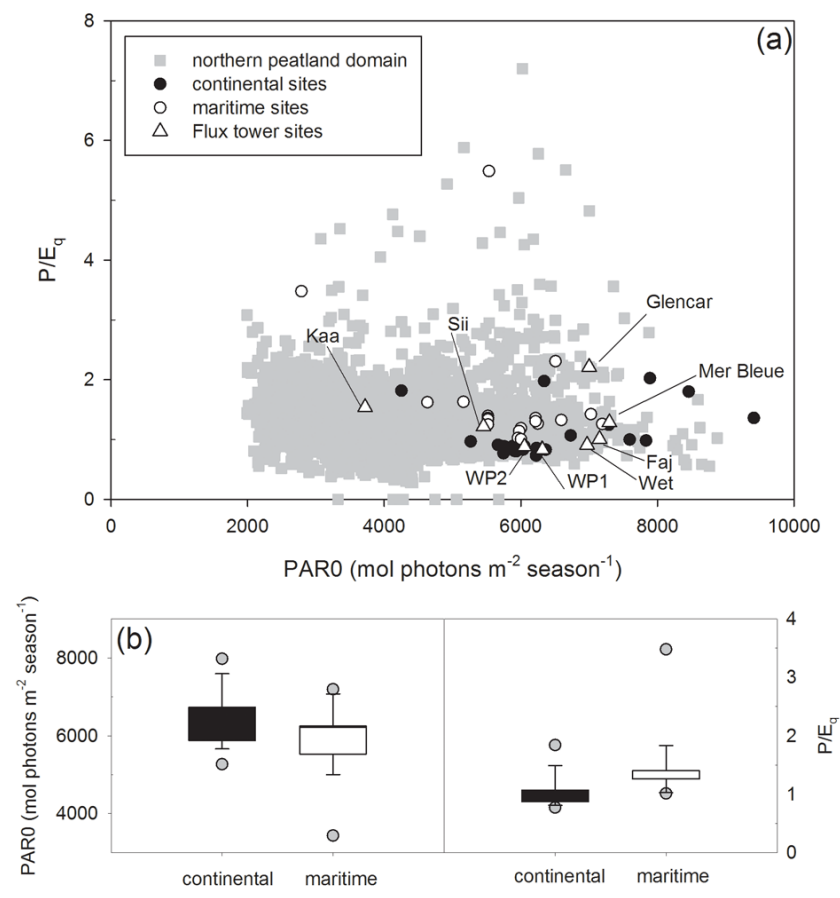

Fig. 4. Sphagnum growth sites in climate space. (a) Climate space of photosynthetically active radiation integrated over the growing season (PAR0) and the ratio between annual precipitation and the annually integrated equilibrium evapotranspiration $\left(P / E_{q}\right)$ of the northern peatland domain (grey dots) based on $0.5 \times 0.5^{\circ}$ gridded instrumental climate data (CLIMATE 2.2 data set) for the period 19601990. The northern peatland extent is from Yu et al. (2010). Open triangles represent the location (in climate space) of 8 peatland sites where flux tower measurements are available (Lund et al., 2010; Koehler et al., 2011): WP1: western peatland 1 (Canada); WP2: western peatland 2 (Canada); Kaa: Kaamanen (Finland); Wet: Polwet (Poland); Faj: Fajemyr (Sweden); Mer Bleue (Canada); Sii: Siikaneva (Finland); and Glencar (Ireland). (b) Box plot of PAR and $P / E_{q}$ values of Sphagnum growth sites for continental and maritime sites. The boxes indicate the 25 th and 75 th percentiles, the whiskers above and below the boxes represent the 10th and 90th percentiles, and the circles represent the 5 th and 95 th percentiles.

continental regions might create a "warm" thermal environment that would allow rapid moss growth during early spring (T. Moore, personal communication, 2011). Finally, the effect of diurnal temperature on moisture availability could partly explain why continental sites exhibit significantly higher moss growth than their maritime counterparts, as a greater diurnal temperature difference in continental settings more likely leads to dew formation that provides additional moisture to mosses.

A sampling bias among the maritime sites could also explain the weak correlation between PAR0, $P / E_{q}$ and moss growth, as well as the overall lower moss growth rates under maritime conditions. As growing season length is relatively long under maritime settings due to mild spring, autumn and winter conditions, it is possible that part of the early spring or 
late autumn growth were not measured in the field, resulting in "minimal" Sphagnum growth estimates that are not representative of the entire growing season length. In a study on oxygen isotope analysis $\left(\delta^{18} \mathrm{O}\right)$ of modern Sphagnum cellulose in northern England, Daley et al. (2010) showed significant differences between the oxygen isotopic signature of Sphagnum cellulose during "winter" (February, March, and November) and "summer" (May to August), which they attributed to direct water uptake from precipitation year-round. In their study, Sphagnum tissues were collected every month of the year, and the $\delta^{18} \mathrm{O}$ value of alpha-cellulose was measured for each of these monthly samples, as well as in corresponding rain-water samples. The isotopic signature of moss samples tracked values obtained from the rain samples, suggesting that water uptake is occurring during "winter" months in some maritime regions and that $\mathrm{CO}_{2}$ uptake and associated plant growth could also be taking place over winter time.

\subsection{Role of Sphagnum growth in regulating peat-C accumulation in northern peatlands}

The response of peatlands to warming conditions is tightly coupled to plant growth and peat decomposition. A recent synthesis of 33 northern peatland sites found highly variable peat-carbon accumulation rates over the past $12000 \mathrm{yr}$, with warming periods coinciding with increases in $\mathrm{C}$ accumulation rates (Yu et al., 2009). Similarly, using 77 sites along a north-south transect across the West Siberian Lowlands, Beilman et al. (2009) found a significant correlation between $\mathrm{C}$ accumulation in the last $2000 \mathrm{yr}$ and modern mean annual temperature, with warmer sites accumulating more C than colder sites over the past 2000 yr. A clear relationship between degree-days and mean annual temperature was also found for long-term peat-C accumulation in Finland and Canada (Clymo et al., 1998), similar to a positive relation between photosynthetically active radiation and growing season length for peat- $\mathrm{C}$ accumulation rates over the last millennium throughout the Northern Hemisphere (Charman et al., 2012). Peatland models have also reported an overall positive effect of warmer temperatures on peat-C sequestration: Under a scenario where production and decomposition had the same sensitivity to temperature, productivity effects dominated and enhanced peat accumulation (Frolking et al., 2003). To reverse this trend, a $Q_{10}$ value of 3 for decomposition rate and a $Q_{10}$ value of 2 for productivity were needed. These results clearly show the important role of NPP in controlling peat-C sequestration, and results from our meta-analysis lend support to these paleoecological evidences and modeling results by showing that moss growth primarily responds to photosynthetically active radiation above $0^{\circ} \mathrm{C}$ over large spatial scales.

\section{Conclusions and future research}

We showed that Sphagnum growth is most strongly controlled by photosynthetically active radiation integrated over the growing season (PAR0), which reflects latitudinal and cloudiness gradients. These results indicate the existence of a global pattern in Sphagnum growth in relation with broadscale bioclimatic and geographic gradients. Since Sphagnum is the main peat builder in most high-latitude peatlands, these patterns have important implications for our understanding of the biogeographic scaling of Sphagnum's carbon sink function. Our results suggest higher peat production under warming climates if there is no moisture stress, in agreement with the idea that warming could lead to a negative feedback from terrestrial ecosystems as a result of increased net primary production and subsequent increased carbon storage (see Field et al., 2007 for a review). This also supports the recent findings in paleoecological studies by Yu et al. (2009), Beilman et al. (2009), Charman et al. (2012), and Loisel and $\mathrm{Yu}$ (2012), which suggest that increasing net primary production under warmer conditions during the Holocene may enhance long-term peat-carbon sequestration, contrary to a hypothesized overriding effect of increased peat decomposition under warming conditions (Ise et al., 2008; Dorrepaal et al., 2009). Specifically, increasing Sphagnum growth under a warming climate may shift the balance of productivity and decomposition, favoring peat-carbon sequestration. However, the relative importance of change in production and decomposition under warm climates in the future will depend on the direction and magnitude of moisture changes, which can best be evaluated with peatland models that incorporate both temperature and moisture functions of production and decomposition processes. To this effect, the present meta-analysis is particularly useful for testing and validating the peatland ecosystem models that are used for future projections, as it clearly shows the important role of PAR0 on peatland biomass production, a component that is neglected in peatland ecosystem models (e.g., Frolking et al., 2010).

Furthermore, important data gaps have been identified from the climate space of PAR0 and available moisture $\left(P / E_{q}\right)$ of the northern peatland domain. Future studies on modern Sphagnum growth and contemporary peatland flux measurements should focus on site in these regions to generate maximum knowledge in climate controls over plant production and carbon sequestration in peatlands.

Finally, it would be interesting to compute PAR0 values separately for the spring, summer, and autumn to evaluate how the Sphagnum carbon fixation potential changes throughout the growing season and to determine when the potential for Sphagnum growth is greatest. In addition, as studies have indicated that Sphagnum $\mathrm{CO}_{2}$ exchange reaches a maximum between 500 and $900 \mu \mathrm{mol} \mathrm{m}^{-2} \mathrm{~s}^{-1}$ (Moore et al., 2002; McNeil and Waddington, 2003), it would be relevant to define a "useful PAR0 for Sphagnum" (PAR0 ${ }_{\mathrm{Sph}}$ ) for each site and see how these optimum values compare to 
the PAR0 values presented in this study. In regions where PAR0 exceeds PAR0 $0_{\text {Sph }}$, some light is "lost", as it is not used by Sphagnum. Conversely, in regions where PAR0 is lower than the theoretical optimum for Sphagnum, the ongoing lengthening of the growing season could promote Sphagnum growth further. Ultimately, the ratio of PAR0 to PAR $0_{S p h}$ could be computed for each season to provide a better understanding of Sphagnum growth potential. The correlation between PAR0 $0_{\text {Sph }}$ and Sphagnum length growth could also be even stronger than the significant correlation between PAR0 and Sphagnum growth presented in this paper.

\section{Supplementary material related to this article is available online at: http://www.biogeosciences.net/9/ 2737/2012/bg-9-2737-2012-supplement.pdf.}

Acknowledgements. We thank Alex Ireland, Eric Klein, Michael Clifford and Steph Hunt for discussion on this topic; Dan Brosseau and Chris Burke provided technical support; and Nigel Roulet, Alex Ireland, Tim Moore and David Currie for helpful comments on previous versions of this manuscript. The research was funded by a US NSF grant (ATM \# 0628455) and by an NSERC fellowship (BESC-D3-362645-2008).

Edited by: E. J. Javaux

\section{References}

Aurela, M., Laurila, T., and Tuovinen, J.-P.: The timing of snow melt controls the annual $\mathrm{CO}_{2}$ balance in a subarctic fen, Geophys. Res. Lett., 31, L16119, doi:10.1029/2004GL020315, 2004.

Bauer, I. E., Tirlea, D., Bhatti, J. S., and Errington, R. C.: Environmental and biotic controls on bryophyte productivity along forest to peatland ecotones, Can. J. Botany, 85, 463-475, 2007.

Beilman, D. W., MacDonald, G. M., Smith, L. C., and Reimer, P. J.: Carbon accumulation in peatlands of West Siberia over the last 2000 years, Global Biogeochem. Cy., 23, GB1012, doi:10.1029/2007GB003112, 2009.

Berendse, F., van Breemen, N., Rydin, H., Buttler, A., Heijmans, M., Hoosbeek, M. R., Lee, J. A., Mitchell, E., Saarinen, T., Vasander, H., and Wallén, B.: Raised atmospheric $\mathrm{CO}_{2}$ levels and increased $\mathrm{N}$ deposition cause shifts in plant species composition and production in Sphagnum bogs, Glob. Change Biol., 7, 591-598, 2001.

Blodau, C.: Carbon cycling in peatlands - A review of processes and controls, Environ. Rev., 10, 111-134, 2002.

Breeuwer, A., Heijmans, M. P. D., Robroek, B. J. M., and Berendse, F.: The effect of temperature on growth and competition between Sphagnum species, Oecologia, 156, 155-167, 2008.

Bubier, J. L., Moore, T. R., and Bledzki, L. A.: Effects of nutrient addition on vegetation and carbon cycling in an ombrotrophic bog, Glob. Change Biol., 13, 1-19, 2007.

Campbell, C., Vitt, D. H., Halsey, L. A., Campbell, I. D., Thormann, M. N., and Bayley, S. E.: Net primary production and standing biomass in northern continental wetlands, Natural Resources Canada, Report NOR-X-369, Canadian Forest Service, Edmonton, 2000.

Chapin III, F. S., Matson, P. A., and Mooney, H. A.: Principles of terrestrial ecosystem ecology, Springer, 2002.

Charman, D., Beilman, D., Blaauw, M., Booth, R. K., Brewer, S., Chambers, F., Christen, J. A., Gallego-Sala, A. V., Harrison, S. P., Hughes, P. D. M., Jackson, S., Korhola, A., Mauquoy, D., Mitchell, F., Prentice, I. C., van der Linden, M., De Vleeschouwer, F., Yu, Z., Alm, J., Bauer, I. E., McCorish, Y., Garneau, M., Hohl, V., Huang, Y., Karofeld, E., Le Roux, G., Loisel, J., Moschen, R., Nichols, J. E., Nieminen, T. M., MacDonald, G. M., Phadtare, N. R., Rausch, N., Sillasoo, Ü., Swindles, G. T., Tuittila, E.-S., Ukonmaanaho, L., Väliranta, M., van Bellen, S., van Geel, B., Vitt, D., and Zhao, Y.: Climate-driven changes in peatland carbon accumulation during the last millennium, P. Natl. Acad. Sci. USA, in review, 2012.

Clymo, R. S.: The growth of Sphagnum: methods of measurement, J. Ecol., 58, 13-49, 1970.

Clymo, R. S. and Hayward, P. M.: The ecology of Sphagnum, in: Bryophyte ecology, edited by: Smith, A. J. E., Chapman \& Hall, London, 229-289, 1982.

Clymo, R. S., Turunen, J., and Tolonen, K.: Carbon accumulation in peatlands, Oikos, 81, 368-388, 1998.

Daley, T. J., Barber, K. E., Street-Perrott, F. A., Loader, N. J., Marshall, J. D., Crowley, S. F., and Fisher, E. H.: Holocene climate variability revealed by oxygen isotope analysis of Sphagnum cellulose from Walton Moss, northern England, Quaternary Sci. Rev., 29, 1590-1601, 2010.

Dorrepaal, E., Aerts, R., Cornelissen, J. H. C., Callaghan, T. V., and van Logtestijn, R. S. P.: Summer warming and increased winter snow cover affect Sphagnum fuscum growth, structure and production in a sub-arctic bog, Glob. Change Biol., 10, 93-104, 2003.

Dorrepaal, E., Toet, S., van Logtestijn, R. S. P., Swart, E., van de Weg, M. J., Callaghan, T. V., and Aerts, R.: Carbon respiration from subsurface peat accelerated by climate warming in the subarctic, Nature, 460, 616-620, 2009.

Field, C. B., Lobell, D. B., Peters, H. A., and Chiariello, N. R.: Feedbacks of terrestrial ecosystems to climate change, Ann. Rev. Env. Resourc., 32, 1-29, 2007.

Freeman, C., Ostle, N., and Kang, H.: An enzymic "latch" on a global carbon store, Nature, 409, 149 pp., 2001.

Frolking, S., Roulet, N. T., Moore, T. R., Richard, P. J. H., Lavoie, M., and Muller, S. D.: Modeling northern peatland decomposition and peat accumulation, Ecosystems, 4, 479-498, 2003.

Frolking, S., Roulet, N. T., Tuittila, E., Bubier, J. L., Quillet, A., Talbot, J., and Richard, P. J. H.: A new model of Holocene peatland net primary production, decomposition, water balance, and peat accumulation, Earth Syst. Dynam., 1, 1-21, doi:10.5194/esd-11-2010, 2010.

Gallego-Sala, A. V., Clark, J. M., house, J. I., Orr, H. G., Prentice, I. C., Smith, P., Farewell, T., and Chapman, S. J.: Bioclimatic envelope model of climate change impacts on blanket peatland distribution in Great Britain, Clim. Res., 34, C911, doi:10.3354/cr00911, 2010.

Gerdol, R.: The growth dynamics of Sphagnum based on field measurements in a temperate bog and on laboratory cultures, J. Ecol., 83, 431-437, 1995. 
Gerdol, R., Petraglia, A., Bragazza, L., Iacumin, P., and Brancaleoni, L.: Nitrogen deposition interacts with climate in affecting production and decomposition rates in Sphagnum mosses, Glob. Change Biol., 13, 1810-1821, 2007.

Gunnarsson, U.: Global patterns of Sphagnum productivity, The Bryologist, 27, 269-279, 2005.

Harrison, S. P., Prentice, I. C., Barboni, D., Kohfeld, K. E., Ni, J., and Sutra, J.-P.: Ecophysiological and bioclimatic foundations for a global plant functional classification, J. Veg. Sci., 21, 300$317,2010$.

Hudson, J. M. G. and Henry, G. H. R.: Increased plant biomass in a High Arctic heath community from 1981 to 2008, Ecology, 90, 2657-2663, 2009.

Ise, T., Dunn, A. L., Wosfy, S. C., and Moorcroft, P. R.: High sensitivity of peat decomposition to climate change through waterTable feedback, Nat. Geosci., 1, 763-766, 2008.

Jones, M. C. and Yu, Z.: Rapid deglacial and early Holocene expansion of peatlands in Alaska, P. Natl. Acad. Sci. USA, 107, 7347-7352, 2010.

Koehler, A.-K., Sottocornola, M., and Kiely, G.: How strong is the current carbon sequestration of an Atlantic blanket bog?, Glob. Change Biol., 17, 309-319, 2011.

Loisel, J. and Yu, Z.: Recent acceleration of carbon accumulation in a boreal peatland, south-central Alaska, J. Geophys. Res.Biogeo., in review, 2012.

Lund, M., Lafleur, P. M., Roulet, N. T., Lindroth, A., Christensen, T. R., Aurela, M., Chojnicki, B. H., Flanagan, L. B., Humphreys, E. R., Laurila, T., Oechel, W. C., Olejnik, J., Rinne, J., Schubert, P., and Nilsson, M. B.: Variability in exchange of $\mathrm{CO}_{2}$ across 12 northern peatland and tundra sites, Glob. Change Biol., 16, 2436-2448, 2010.

Luken, J. O.: Zonation of Sphagnum mosses: interactions among shoot growth, growth form, and water balance, The Bryologist, 88, 374-379, 1985.

Malmer, N. and Wallén, B.: Input rates, decay losses and accumulation rates of carbon in bogs during the last millennium: internal processes and environmental changes, The Holocene, 14, 111117, 2004.

Mauquoy, D., Engelkes, T., Groot, M. H. M., Markesteijn, F., Oudejans, M. G., van der Plicht, J., and van Geel, B.: High-resolution records of late-Holocene climate change and carbon accumulation in two north-west European ombrotrophic peat bogs, Palaeogeogr. Palaeocl., 186, 275-310, 2002.

McNeil, P. and Waddington, J. M.: Moisture controls on Sphagnum growth and $\mathrm{CO}_{2}$ exchange on a cutover bog, J. Appl. Ecol., 40, 354-367, 2003.

Menzel , A., Sparks, T. H., Estrella, N., Koch, E., Aasa, A., Ahas, R., Alm-Kübler, K., Bissolli, P., Braslavska, O., Briede, A., Chmielewski, F. M., Crepinsek, Z., Curnel, Y., Dahl, A., De Fila, C., Donnelly, A., Filella, Y., Jatcza, K., Måge, F., Mestre, A., Nordli, O., Peñuelas, J., Pirinen, P., Remišová, V., Scheifinger, H., Striz, M., Susnik, A., van Vliet, A. J. H., Wielgolaski, F.-E., Zach, S., and Zust, A.: European phenological response to climate change matches the warming pattern, Glob. Change Biol., 12, 1969-1976, 2006.

Moore, T. R.: Growth and net production of Sphagnum at five fen sites, subarctic eastern Canada, Can. J. Botany, 67, 1203-1207, 1989.
Moore, T. R., Bubier, J. L., Frolking, S. E., Lafleur, P. M., and Roulet, N. T.: Plant Biomass and Production and $\mathrm{CO}_{2}$ Exchange in an Ombrotrophic Bog, J. Ecol., 90, 25-36, 2002.

Moore, T. R., Lafleur, P. M., Poon, D. M. I., Heumann, B. W., Seaquist, J. W., and Roulet, N. T.: Spring photosynthesis in a cool temperate bog, Glob. Change Biol., 12, 2323-2335, 2006.

Nemani, R. R., Keeling, C. D., Hashimoto, H., Jolly, W. M., Piper, S. C., Tucker, C. J., Myneli, R. B., and Running, S. W.: Climatedriven increases in global terrestrial net primary production from 1982 to 1999, Science, 300, 1560-1563, 2003.

Prentice, I. C., Sykes, M. T., and Cramer, W.: A simulation model for the transient effects of climate change on forest landscapes, Ecol. Model., 65, 51-70, 1993.

Rydin, H. and Jeglum, J.: The Biology of Peatlands, Oxford University Press, Oxford, 2006.

Schwartz, M. D., Ahas, R., and Aasa, A.: Onset of spring starting earlier across the Northern Hemisphere, Glob. Change Biol., 12, 343-351, 2006.

Skre, O. and Oechel, W. C.: Moss functioning in different taiga ecosystems in interior Alaska, Oecologia, 48, 50-59, 1981.

Steltzer, H. and Post, E.: Seasons and life cycles, Science, 324, 886887, 2009.

Titus, J. E. and Wagner, D. J.: Carbon balance for two Sphagnum mosses: water balance resolves a physiological paradox, Ecology, 65, 1765-1774, 1984.

Turetsky, M. R., Crow, S. E., Evans, R. J., Vitt, D. H., and Wieder, R. $\mathrm{K}$.: Trade-offs in resource allocation among Sphagnum species control decomposition in boreal peatlands, J. Ecol., 96, 12971305, 2008.

van Breemen, N.: How Sphagnum bogs down other plants, Trends Ecol. Evol., 10, 270-275, 1995.

Weltzin, J. F., Harth, C., Bridgham, S. D., Pastor, J., and Vonderharr, M.: Production and microtopography of bog bryophytes: response to warming and water-Table manipulations, Oecologia, 128, 557-565, 2001.

Wieder, R. K.: Primary production in boreal peatlands, in: Boreal peatland ecosystems, edited by: Wieder, R. K. and Vitt, D. H., Ecological Studies 188, Springer-Verlag Berlin Heidelberg, 145163, 2006.

Wieder, R. K. and Lang, G. E.: Net primary production of the dominant bryophytes in a Sphagnum-dominated wetland in West Virginia, The Bryologist, 86, 280-286, 1983.

Yu, Z., Beilman, D. W., and Jones, M. C.: Sensitivity of northern peatland carbon dynamics to Holocene climate change, in: Carbon cycling in northern peatlands, edited by: Baird, A. J., Belyea, L. R., Comas, X., Reeve, A., and Slater, L., Geophysical Monograph 184, American Geophysical Union, Washington DC, 5569, 2009.

Yu, Z., Loisel, J., Brosseau, D. P., Beilman, D. W., and Unt, S. J.: Global peatland dynamics since the Last Glacial Maximum, Geophys. Res. Lett., 37, L13402, doi:10.1029/2010GL043584, 2010.

Zar, J. H.: Biostatistical analysis, 5th edition, Pearson Prentice Hall, 2010. 